\title{
Pulmonary Function Tests in Different Phases of Mensrual Cycle in Young Girls of 18-22 Years Age
}

\author{
Sunita Manikrao Handergulle ${ }^{1}$, Savita Satyanarayan Somani ${ }^{2}$ \\ ${ }^{1}$ Professor and Head, ${ }^{2}$ Assistant Professor, Dept of Physiology, SRTRGMC Ambajogai.
}

\begin{abstract}
Background : Women undergo hormonal changes especially during reproductive life. Menstrual cycle is an integral part of life of women. The changes in the level of estrogen and progesterone associated with menstrual cycle not only affects the reproductive system but also affects different systems including respiratory system.

Aim and Objectives: The aim of the study is to carry out pulmonary function tests during menstrual, proliferative and secretory phase of menstrual cycle in young girls.

Materials and Methods: The study was carried out in 50 healthy young girls of age between 18-22 years. Pulmonary function tests were done in all the three phases of menstrual cycle. The Analysis of Variance (ANOVA) was used to compare the means of various parameters in three phases of menstrual cycle.

Result: It was observed that FVC , FEV1, FEF25-75\%, PEFR and MVV were statistically highly significant $(\mathrm{p}<0.01)$ in secretory phase as compared to menstrual phase and proliferative phase of menstrual cycle. These parameters are also statistically highly significant $(p<0.01)$ in proliferative phase as compared to menstrual phase. The difference in FEV1\%in different phases is statistically non significant.

Conclusion: Pulmonary function tests parameters were higher during secretory phase as compared to proliferative and menstrual phase. Main reason behind this could be the effect of progesterone on respiratory system.
\end{abstract}

Key words : Pulmonary Function Tests, Menstrual cycle, Progesterone, Estrogen

\section{INTRODUCTION:}

$\mathrm{T}$ The reproductive system of women shows regular cyclical changes that teleologically may be regarded as periodic preparation for fertilization and pregnancy. In the human the monthly sexual cycle has an average duration of 28 days and divided into three phases: menstrual, proliferative (follicular) and secretory (luteal) phase. ${ }^{1}$ The day of menstruation is considered as first day of menstrual cycle. This cycle is regulated by cyclical production of estrogen and progesterone by ovary and also by lutenising and follicle stimulating hormone by anterior pituitary. ${ }^{2}$ These cyclical changes apart from reproductive system also affect the different systems of the body and also the respiratory system. $^{3}$

Hormonal levels are altered according to the body metabolism. Lungs are meant to adapt the metabolism need of the body. Literature also 
mentioned that estrogen and progesterone levels strengthen the respiratory musculature and increase the relaxation of bronchial smooth muscles. ${ }^{4}$ Dynamic lung function represents the status of respiratory muscles and airway. Hence in the present research work we made an attempt to study the dynamic lung function parameters in different phases of menstrual cycle.

\section{AIMAND OBJECTIVES:}

The aim of the study is to carry out pulmonary function tests during menstrual, proliferative and secretory phase of menstrual cycle in young girls.

\section{MATERIALSAND METHODS:}

The study was carried out, in 50 healthy young girls of 18-22 years age from medical campus in three different phases of menstrual cycle i.e. menstrual, proliferative(follicular) and secretory phase (luteal). All were from the middle socio economic class. The approval for the study was obtained from Institutional Ethics committee.

\section{Selection criteria}

- Age group between 18-22 years.

- They had regular menstrual cycle with an average length of 28-30 days

\section{Exclusion criteria}

- Volunteers with irregular menses and taking oral contraceptive pills.

- Volunteers with menorrhagia and oligomenorrhoea.

- Volunteers having history of diabetes mellitus and cardiovascular diseases.

- Those having history of addiction of tobacco, alcohol and smoking.
All the volunteers were assessed for pulmonary function tests during menstrual phase i.e. around 2nd - 4th day of menstrual cycle, proliferative phase i.e. 10th - 12 th day menstrual cycle and secretory phase i.e. around 22nd - 24th day of their menstrual cycle. The phases were estimated according to their menstrual history and date of last menstrual period.

All tests were carried out in the morning hours. Before starting the procedure, physical examination of all the girls was done with the help of predesigned proforma and written informed consent form was signed by all of them. The procedure was explained to all participants to alleviate fear. After giving rest for 5 minutes, Pulmonary Function Tests were carried out by computerised MEDSPIROR by two manoeuvres ${ }^{5}$.

\section{FVC Manoeuvre :}

Subjects were asked to take deep breath and execute fast, forceful expiration in the mouthpiece of equipment while closing the nose. ${ }^{5}$

\section{MVV Manoeuvre :}

Subjects were asked to respire as rapid as and as deep as possible, for 12 seconds into the mouthpiece of equipment.

Following parameters were taken in the consideration :

1) FVC(lit)- Forced vital capacity

2) FEV1 (lit)-Forced expiratory volume in one second

3) $\mathrm{FEV} 1 \%$ - FEV1/FVC ratio

4) FEF $25-75 \%$ (lit/sec)- Mean forced expiratory flow during the middle of FVC.

5) PEFR (lit/sec)-Peak expiratory flow rate.

6) MVV(lit/min)- Maximum Voluntary Ventilation 


\section{Statistical analysis:}

The mean and standard deviation (SD) of each parameter was calculated. The Analysis of Variance (ANOVA) was used to compare the means of various parameters in three phases of menstrual cycle.

\section{RESULTS:}

Table No.1: Pulmonary function tests in different phases of menstrual cycle

\begin{tabular}{|c|c|c|c|c|c|}
\hline Parameters & $\begin{array}{c}\text { Menstrual } \\
\text { phase } \\
\text { (Mean } \pm \text { SD) }\end{array}$ & $\begin{array}{c}\text { Proliferative } \\
\text { phase } \\
\text { (Mean } \pm \text { SD) }\end{array}$ & $\begin{array}{c}\text { Secretory } \\
\text { phase } \\
\text { (Mean } \pm \text { SD) }\end{array}$ & $\begin{array}{c}\text { ANOVA } \\
\text { (p value- } \\
\text { two } \\
\text { tailed) }\end{array}$ & $\begin{array}{c}\text { Tukey's } \\
\text { Multiple } \\
\text { comparision } \\
\text { test }\end{array}$ \\
\hline $\begin{array}{c}\text { FVC } \\
\text { (in liters) }\end{array}$ & $1.822 \pm 0.097$ & $1.961 \pm 0.14$ & $2.145 \pm 0.141$ & $<0.0001$ & $\mathrm{a}, \mathrm{b}, \mathrm{c}$ \\
\hline $\begin{array}{c}\text { FEV } \\
\text { (in liters) }\end{array}$ & $1.673 \pm 0.123$ & $1.805 \pm 0.094$ & $1.947 \pm 0.063$ & $<0.0001$ & $\mathrm{a}, \mathrm{b}, \mathrm{c}$ \\
\hline $\begin{array}{c}\text { FEV } \% \\
\text { (FEV } \mathbf{1} \text { /FVC } \\
\text { ratio) }\end{array}$ & $91.85 \pm 4.537$ & $92.18 \pm 2.521$ & $91.09 \pm 5.818$ & $>0.05$ & $\mathrm{~N} . \mathrm{S}$ \\
\hline $\begin{array}{c}\text { FEF 25- } \\
\mathbf{7 5 \%} \text { (lit/sec }\end{array}$ & $2.752 \pm 0.568$ & $3.498 \pm 0.347$ & $3.996 \pm 0.173$ & $<0.0001$ & $\mathrm{a}, \mathrm{b}, \mathrm{c}$ \\
\hline $\begin{array}{c}\text { PEFR } \\
\text { (lit/sec) }\end{array}$ & $3.87 \pm 0.453$ & $4.412 \pm 0.314$ & $5.316 \pm 0.207$ & $<0.0001$ & $\mathrm{a}, \mathrm{b}, \mathrm{c}$ \\
\hline $\begin{array}{c}\text { MVV } \\
\text { (lit/min) }\end{array}$ & $84.14 \pm 4.01$ & $90.24 \pm 3.364$ & $98.6 \pm 1.539$ & $<0.0001$ & $\mathrm{a}, \mathrm{b}, \mathrm{c}$ \\
\hline
\end{tabular}

S.D - Standard Deviation, H.S - Highly significant, N.S - Non Significant

a - Highly significant difference between Menstrual and Proliferative phase by Tukey's Multiple comparision test.

b - Highly significant difference between Menstrual and Secretory phase by Tukey's Multiple comparison test.

c - Highly significant difference between Proliferative and Secretory phase by Tukey's Multiple comparison test.

In Table No.1, pulmonary function tests were compared during different phases of menstrual cycle. It was observed that FVC, FEV1, FEF25$75 \%$, PEFR and MVV were statistically highly significant $(\mathrm{p}<0.01)$ in secretory phase as compared to menstrual phase and proliferative phase of menstrual cycle. These parameters are also statistically highly significant $(\mathrm{p}<0.01)$ in proliferative phase as compared to menstrual phase. The difference in FEV1\% in different phases is statistically non-significant.

\section{DISCUSSION:}

In the present study, FVC , FEV1, FEF25-75\%, PEFR and MVV were significantly $(p<0.001)$ altered in secretory phase as compared to menstrual phase and proliferative phase, reflecting a significant increase in pulmonary activity.

Our result of FVC and FEV1, PEFR is in accordance with the study of Goyal et $\mathrm{al}^{4}$, Dr.Harleen Kaur et $\mathrm{al}^{6}$, Jasrotia $\mathrm{RB}^{7}$, Gavali $\mathrm{MY}^{8}$, Dimple Arora et. al ${ }^{9}$ Rajesh $\mathrm{CS}^{10}$. The values of FEV1\% in different phases and difference were in accordance with Hebbar KR et $\mathrm{al}^{11} \mathrm{FEF} 25-75 \%$ is a sensitive index of small airways and it varies like that of PEFR. These findings are consistent with Dimple Arora et $\mathrm{al}^{9}$. MVV is an effort dependent manuever. Increase in MVV in secretory phase matches with Jasrotia $\mathrm{RB}^{7}$ Da silva $\mathrm{SB}$ et $\mathrm{al}^{12}$ and Das $\mathrm{TK}^{13}$ did not find significant difference in FVC and FEV1 in different phases of menstrual cycle.

The variations in pulmonary function during different phases follow a cyclical pattern which possibly could be due to action of various hormones. ${ }^{13}$ The most probable reason for increase in lung function parameters during the secretory phase of menstrual cycle is the hyperventilation associated with increased level of progesterone in this phase. ${ }^{14}$ Progesterone induces hyperventilation through both central medullary and peripheral receptors during the secretory phase. Periodical hyperventilation improves respiratory muscle strength and lung capacities. ${ }^{8,9,10}$ Hormones also affect the bronchomotor tone. Progesterone could cause relaxation of bronchial smooth muscle. ${ }^{9}$ This could be resulting in decrease in airway resistance and improvement in flow rates in secretory phase. During proliferative phase, estrogen might also 
have smooth muscle relaxant effect. ${ }^{9,15}$ Literature also mentioned that asthmatic females worsen their symptoms just before menstrual bleeding. ${ }^{7.16} \mathrm{~A}$ significant increase in pulmonary function has been reported in females taking oral contraceptives. ${ }^{11,17}$ Hormone pills containing progesterone decreases the resistance offered by small bronchioles. Thus cyclical hormonal changes reflect higher pulmonary function test parameter values in secretory phase followed by proliferative phase and least during menstrual phase.

\section{IMPLICATIONS}

Though young girls of present study did not complain of any respiratory symptoms during menstrual phase, yet significantly increased level of progesterone during secretory phase should be kept in mind while prescribing bronchodilator drugs. Also conditions like premenstrual asthma can be better tackled with the help of these observations. Today, young women are under many kinds of stress which may be precipitated during LL phase of menstrual cycle.

\section{LIMITATIONS}

Further study is required to see the effect of ovarian hormones like estrogen and progesterone on bronchial smooth muscle.

\section{CONCLUSION}

Improvement in pulmonary functions during secretory phase as compared to proliferative and menstrual phase is due to bronchodilator effect of progesterone. Higher values of lung functions during proliferative phase as compared to menstrual phase is due to estrogen which might also have smooth muscle relaxant effect.

\section{REFERENCES}

1. Arthur C. Guyton, John E. Hall. Female physiology before pregnancy and female hormones. In: Text book of medical physiology. 11th ed. London: Elsevier; 2006. 1011-26.

2. Kim E. Barrett, Susan Barman, Scott Boitano, Heddwen Brooks,: The gonads: Development and function of reproductive system. In: Ganongs' Review of Medical Physiology. 23rd edition. United States of America: The McGraw-Hill Companies, Inc; 2010; 411-16.

3. Nandini R, Subhashini AS. Variation in pulmonary functions with the phases of the menstrual cycle in adolescent females. $\mathrm{J}$ clin Diag Res. 2012; 6(2): 173-75.

4. Manish Goyal SK, Dwivedi, Ajit singh Rajput. Effect of different phases of menstrual cycle on lung functions in young girls of 18-24 years age. International Journal of Research in Medical Sciences. Feb-2017; 5 (2): 612-18.

5. Shankar PS. Pulmonary function tests \& interpretation in health \& diseases. 1st ed. New Delhi: CBS Publisher and distributors, pvt.ltd; 1998.

6. Harleen Kaur, Poonam G Kolli, Rajiv Arora, Seema Maini. Effect of different phases of menstrual cycle on pulmonary functions. Indian Journal of Basic and Applied Medical Research. Dec.2015; 5 (1): 266-69.

7. Rajani Bala Jasrotia1, Arvind Kanchan, Jaman Mohan Harsoda. Effect of menstrual cycle on pulmonary functions and respiratory efficiency. International Archives of Integrated Medicine. July 2016;3(7):233-38. 
8. Gavali MY, Gavali XV, Gadkari JV, Patil KB. Influence of menstrual cycle on lung functions in young healthy medical students. International J. of Healthcare \& Biomedical Research. October 2013; 2(1):30-34.

9. Dimple Bajaj Arora, Parminder Kaur Sandhu, Sukhinder Dhillon, Antepreet Arora, Nimarpreet Kaur. Respiratory functions in asthamatic and normal women during different phases of menstrual cycle. Pak J Physiol. 2015; 11 (2): 3-7.

10. Rajesh CS., Gupta and Vaney. Status of pulmonary function tests in adolescent females of Delhi. Indian J Physiol Pharmacol. 2000; 44 (4): 442-448.

11. Raksha Hebbar. K: Comparative Study of Pulmonary Function Tests in Women in Different Phases of Menstrual Cycle with and Without Contraceptive Pills. IOSR Journal of Dental and Medical Sciences. Jul.- Aug. 2013;8(5):21-25.

12. Da Silva SB, Viana EDSR, De Sousa MB: Changes in peak expiratory flow and respiratory strength during the menstrual cycle. Respir Physiol Neurobiol. 2006; 150: 211-9.
13. Das TK: Effect of menstrual cycle on timing and depth of breathing at rest. Indian J Physiol Pharmacol. 1998; 42 (4): 498-502.

14. Beyon HZ, Garbet ND, Barnes PJ. Severe premenstrual exacerbation of asthma. The effect of intramuscular progesterone. Lancet. 1988; 13 (2): 370-72.

15. Elizabeth A, Townsend, Venkata Chalem Santhish, Michael A Thompson, Christina M Pabelick, Y.S. Prakash: Estrogen effects on human air way smooth muscle involve cAMP and protein kinase A. Am J. of PhysiologyLung cellular and molecular Physiology. Nov 2012; 303(10): L-923-L-928.

16. Catherine L, Haggerty, Robert B Ness, Sheryl Kelesy, Grant W Waterer. The impact of estrogen and progesterone on asthma. Annals of Allergy: Asthma and immunology, Mar 2003; 90(3): 84-91.

17. Kumar p, Singh S, Singh U, Verma P. Oral contraceptive pills decrease airway resistance in healthy north Indian women. Indian J Med Sci. 2011; 65: 64-68.

Received on 15/10/2017 Revised on 04/12/2017 Accepted on 08/12/2017 